Eshmuratov Bakhodir Beshimovich, cand. tech. sciences, Tashkent Scientific Research Institute of Chemical Technology of the Republic of Uzbekistan, Tashkent

E-mail:bbeshmuratov@mail.ru

Karimov Masud Ubaydulla ugli, doc. tech. sciences, Tashkent Scientific Research Institute of Chemical Technology of the Republic of Uzbekistan, Tashkent E-mail:adler_219@mail.ru Jalilov Abdulakhat Turapovich, academician, doc. chem. Sciences, prof., Tashkent Scientific Research Institute of Chemical Technology of the Republic of Uzbekistan, Tashkent E-mail:a.t.djalilov@mail.ru

\title{
SYNTHESIS AND STUDY OF DEMULSIFIERS BASED ON POLYCARBOXYLATE ETHERS
}

\begin{abstract}
The article presents the relevance of the use of demulsifiers in oil production. The results of studies of the obtained demulsifier using IR spectroscopy are shown, and the results of the study of the kinetics of the approximate and refined effective dosage of the demulsifier DE-1 in different fields are presented.
\end{abstract}

Keywords: demulsifier, IR spectroscopy, approximate and refined effective, polycarboxylate ethers.

Demulsification is the destruction of the emulsion in the oil and water phases. From a technological point of view, oil producers are interested in two aspects of de-emulsification: the speed at which destruction occurs and the amount of water remaining in the crude oil after preparation. Extracted oil should usually comply with the specifications of the company and pipeline transport; therefore, the oil is desalted and dehydrated beforehand in the oil fields. A low content of water and chlorides in the oil is required to reduce the corrosive effects and salt deposits. At refineries, the main task is to remove inorganic salts (mainly chloride) from crude oil before they cause corrosion or other harmful effects on refining equipment. When this salt is removed from the crude oil by washing with fresh water on the ELOU.

Extracted oil emulsions have a degree of kinetic stability due to the formation of interfacial films surrounding water droplets. In order to separate the emulsion into oil and water, the interfacial film must be destroyed, resulting in coalescence of the droplets and separation of the aqueous phase. Therefore, the destabilization of emulsions is very closely related to the destruction of this interfacial film. Factors affecting the phase boundary and, consequently, the stability of emulsions were discussed earlier (the dispersive properties of formation water and oil, water content, natural emulsifiers, particulate matter, etc.) [1-6].

We obtained polycarboxylate ethers based on polyacrylonitrile.

After processing of polyacrylonitrile with sulfuric acid and ethyl alcohol, followed by neutralization, some changes in the structure of the raw materials are manifested. These changes can be seen in the IR spectrum of (Fig. 1). 


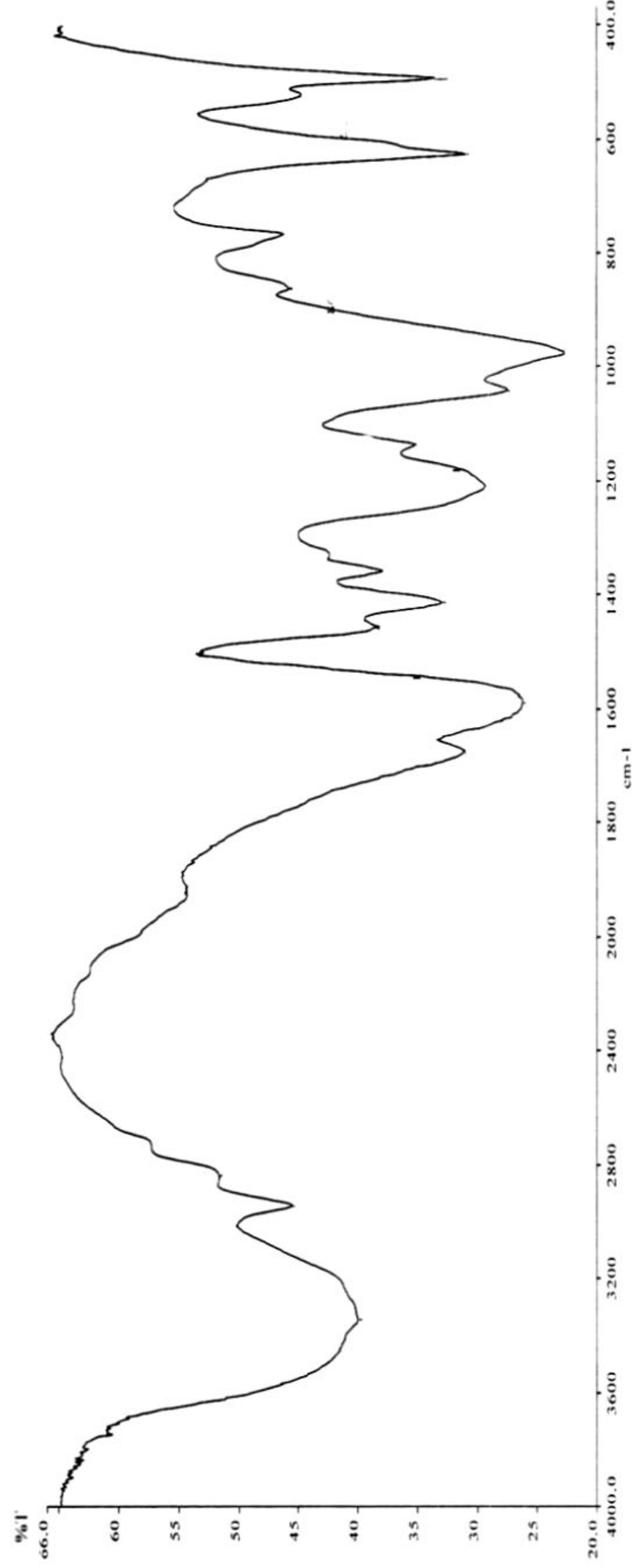

After processing, the absorption bands in the region of $3000-3200 \mathrm{~cm}^{-1}$ disappeared and new absorption bands appeared in the region of $3346 \mathrm{~cm}^{-1}$. This shows that the functional group $-\mathrm{CONH}_{2}$ has changed its structure to - $\mathrm{CONH}$-chemical bonds. This shows that the absorption bands are asymmetric to the valence vibrations in the region of 1150 $-1260 \mathrm{~cm}^{-1}$, and the absorption bands characteristic of symmetric stretching vibrations manifest themselves in the region of $1010-1080 \mathrm{~cm}^{-1}$.

Used glue, as a raw material for the production of the demulsifier, has in its structure hydrophilic $\left(-\mathrm{COONa},-\mathrm{COOC}_{2} \mathrm{H}_{5}-\mathrm{CONH}_{2}\right)$ and $-\mathrm{C}-\mathrm{C}$ chemical bonds.

In (tab. 1-4) shows the results of the study of the kinetics of water excretion of the tested demulsifiers in the conditions of the field Toshli. The analysis of laboratory studies showed that the oil field selected from the well and the gas-measuring unit is homogeneous: it is similar in chemical composition and properties to paraffin type (average $3.7 \%$ wt.), High resin (average 19\% wt.) according to the sulfur content - high-sulphurous, according to chloride salts and mechanical impurities belong to the third group.

According to the test results (Table 1), it can be seen that when introduced into the initial water-oil emulsion in the amount of $240 \mathrm{~g} / \mathrm{t}$, there is no negative effect on the preparation process, dehydration and desalting of oil: the degree of dehydration is $60.11 \%$, and the residual content of chloride salts $2.51 \mathrm{~g} / \mathrm{l}$.

The results of the study (Table 2) show that the demulsifier, when introduced into the oil-water emulsion, shows a high demulsifying ability. With a maximum specific consumption of $300 \mathrm{~g} / \mathrm{t}$, the degree of dehydration is $29.32 \%$, the residual water content in oil is $70.68 \%$. The content of chloride salts in oil decreased from 5.94 to $3.39 \mathrm{~g} / \mathrm{l}$. When a demulsifier is introduced into the water-oil emulsion, the released water does not become cloudy, there is no clear phase interface, adhesion to the tube walls is present, there is no intermediate layer, no precipitate forms. 
Table 1.- The results of the study of the kinetics of the approximate and refined effective dosage of the obtained demulsifier at a test temperature of $90^{\circ} \mathrm{C}$ for Western Toshli oil

\begin{tabular}{|c|c|c|c|c|c|c|c|c|c|c|c|c|c|c|c|c|}
\hline \multirow[b]{2}{*}{ № } & \multirow{2}{*}{ 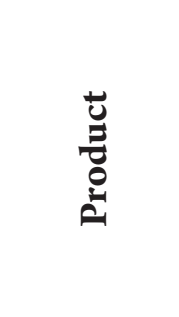 } & \multirow{2}{*}{$\begin{array}{l}+ \\
00 \\
0 \\
0 \\
0 \\
0 \\
0 \\
0\end{array}$} & \multicolumn{11}{|c|}{$\begin{array}{c}\text { The amount of released water,\% } \\
\text { Time, min }\end{array}$} & \multirow{2}{*}{ 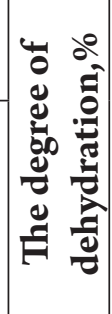 } & \multirow{2}{*}{ 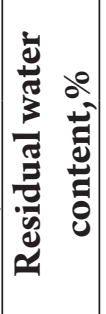 } & \multirow{2}{*}{ 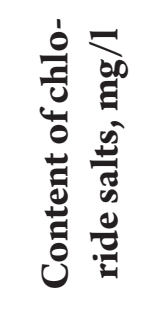 } \\
\hline & & & 5 & 10 & 15 & 20 & 30 & 40 & 50 & 60 & 75 & 90 & 12 & & & \\
\hline \multicolumn{17}{|c|}{ Estimated efficiency, the value of bound water $-44.6 \%$} \\
\hline 1. & Blank test & 0 & 0.00 & 0.00 & 0.00 & 0.00 & 0.00 & 0.41 & 0.82 & 0.82 & 1.64 & 3.28 & 4.10 & 9.19 & 90.81 & 8090.9 \\
\hline 2. & $\begin{array}{l}\text { obtained } \\
\text { demulsifier }\end{array}$ & 150 & 0.00 & 2.34 & 11.69 & 17.14 & 21.03 & 21.81 & 22.59 & 23.37 & 24.93 & 25.71 & 25.71 & 57.64 & 42.36 & 2625.99 \\
\hline 3. & $\begin{array}{l}\text { obtained } \\
\text { demulsifier }\end{array}$ & 200 & 0.00 & 3.71 & 11.12 & 16.30 & 21.49 & 21.49 & 22.23 & 22.97 & 23.71 & 24.45 & 24.45 & 54.83 & 45.17 & 2827.49 \\
\hline 4. & $\begin{array}{l}\text { obtained } \\
\text { demulsifier }\end{array}$ & 240 & 0.00 & 2.37 & 11.83 & 19.71 & 23.66 & 25.23 & 26.02 & 26.02 & 26.81 & 26.81 & 26.81 & 60.11 & 39.89 & 2314.87 \\
\hline 5. & $\begin{array}{l}\text { obtained } \\
\text { demulsifier }\end{array}$ & 300 & 0.00 & 3.04 & 12.92 & 18.24 & 21.28 & 23.56 & 24.32 & 25.08 & 25.84 & 25.84 & 25.84 & 57.94 & 42.06 & 2515.70 \\
\hline \multicolumn{17}{|c|}{ Estimated efficiency, the value of bound water $-42 \%$} \\
\hline 1. & Blank test & 0 & 0.00 & 0.00 & 0.00 & 0.00 & 0.00 & 0.80 & 0.80 & 0.80 & 1.20 & 1.60 & 2.40 & 5.71 & 94.29 & 13045.9 \\
\hline 2. & $\begin{array}{l}\text { obtained } \\
\text { demulsifier }\end{array}$ & 220 & 0 & 7.60 & 12.92 & 15.20 & 18.24 & 20.52 & 21.28 & 21.28 & 21.28 & 22.04 & 22.80 & 54.29 & 45.71 & 12393.61 \\
\hline 3. & $\begin{array}{l}\text { obtained } \\
\text { demulsifier }\end{array}$ & 260 & 0 & 7.79 & 13.24 & 16.36 & 19.48 & 21.03 & 21.81 & 22.59 & 23.37 & 23.37 & 23.76 & 56.57 & 43.43 & 6003.15 \\
\hline
\end{tabular}

Table 2.- The results of the study of the kinetics of the estimated effective dosage of the obtained demulsifier at a test temperature of $90{ }^{\circ} \mathrm{C}$ for East Tashli oil (the value of bound water is $55.6 \%$ )

\begin{tabular}{|c|c|c|c|c|c|c|c|c|c|c|c|c|c|c|c|c|}
\hline \multirow{2}{*}{ № } & \multirow{2}{*}{ Product } & \multirow{2}{*}{$\begin{array}{l}\underset{00}{00} \\
0 \\
0 \\
0 \\
0 \\
0 \\
0\end{array}$} & \multicolumn{11}{|c|}{$\begin{array}{c}\text { The amount of released water,\% } \\
\text { Time, min }\end{array}$} & \multirow{2}{*}{ 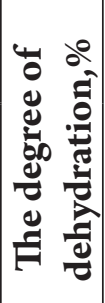 } & \multirow{2}{*}{ 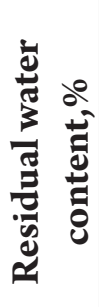 } & \multirow{2}{*}{ 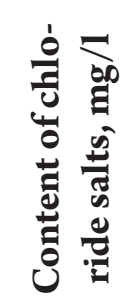 } \\
\hline & & & 5 & 10 & 15 & 20 & 30 & 40 & 50 & 60 & 75 & 90 & 120 & & & \\
\hline 1. & Blank test & 0 & 0.00 & 0.00 & 0.00 & 0.00 & 0.00 & 0.00 & 0.00 & 0.00 & 0.00 & 0.80 & 3.20 & 5.76 & 94.24 & 5940.9 \\
\hline 2. & $\begin{array}{l}\text { obtained } \\
\text { demulsifier }\end{array}$ & 150 & 0.00 & 0.00 & 0.08 & 1.52 & 4.56 & 6.84 & 7.60 & 9.88 & 12.16 & 14.44 & 17.48 & 31.44 & 68.56 & 3033.83 \\
\hline 3. & $\begin{array}{l}\text { obtained } \\
\text { demulsifier }\end{array}$ & 200 & 0.00 & 0.00 & 0.08 & 3.75 & 6.75 & 9.01 & 9.76 & 12.01 & 13.51 & 14.26 & 17.26 & 31.05 & 68.95 & 3106.12 \\
\hline 4. & $\begin{array}{l}\text { obtained } \\
\text { demulsifier }\end{array}$ & 240 & 0.00 & 0.00 & 0.08 & 5.32 & 9.12 & 11.40 & 14.44 & 15.20 & 17.48 & 19.76 & 22.04 & 39.64 & 60.36 & 2458.03 \\
\hline 5. & $\begin{array}{l}\text { obtained } \\
\text { demulsifier }\end{array}$ & 300 & 0.00 & 0.00 & 0.15 & 5.48 & 7.56 & 10.08 & 11.64 & 12.23 & 13.49 & 15.11 & 16.30 & 29.32 & 70.68 & 3387.70 \\
\hline
\end{tabular}


Table 3.- Results of the study of the kinetics of the approximate and refined effective dosage of the obtained demulsifier at a test temperature of $90^{\circ} \mathrm{C}$ for northern shurtan oil

\begin{tabular}{|c|c|c|c|c|c|c|c|c|c|c|c|c|c|c|c|c|}
\hline \multirow[b]{3}{*}{ № } & \multirow[b]{3}{*}{ Product } & \multirow{3}{*}{$\begin{array}{l}+ \\
00 \\
0 \\
0 \\
0 \\
0 \\
0 \\
0 \\
0\end{array}$} & \multicolumn{11}{|c|}{ The amount of released water, $\%$} & \multirow{3}{*}{ 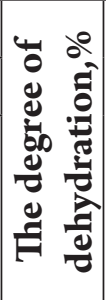 } & \multirow{3}{*}{ 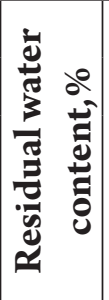 } & \multirow{3}{*}{ 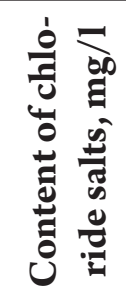 } \\
\hline & & & \multicolumn{11}{|c|}{ Time, min } & & & \\
\hline & & & 5 & 10 & 15 & 20 & 30 & 40 & 50 & 60 & 75 & 90 & 120 & & & \\
\hline \multicolumn{17}{|c|}{ Estimated efficiency, the value of bound water $-54 \%$} \\
\hline 1. & Blank test & 0 & 0.00 & 0.00 & 0.00 & 0.00 & 0.00 & 0.00 & 0.00 & 0.00 & 0.80 & 1.60 & 2.40 & 4.44 & 95.56 & 7118.3 \\
\hline 2. & $\begin{array}{l}\text { obtained } \\
\text { demulsifier }\end{array}$ & 150 & 0.00 & 0.00 & 2.19 & 5.85 & 8.05 & 17.56 & 23.41 & 26.33 & 28.53 & 29.26 & 29.99 & 67.25 & 32.75 & 2133.32 \\
\hline 3. & $\begin{array}{l}\text { obtained } \\
\text { demulsifier }\end{array}$ & 200 & 0.00 & 0.00 & 3.00 & 7.51 & 18.01 & 24.77 & 28.52 & 29.27 & 30.02 & 30.77 & 30.77 & 68.99 & 31.01 & 2034.24 \\
\hline 4. & $\begin{array}{l}\text { obtained } \\
\text { demulsifier }\end{array}$ & 240 & 0.00 & 0.00 & 2.22 & 7.41 & 12.60 & 25.19 & 28.16 & 28.90 & 29.64 & 30.38 & 31.12 & 69.78 & 30.22 & 1994.81 \\
\hline 5. & $\begin{array}{l}\text { obtained } \\
\text { demulsifier }\end{array}$ & 300 & 0.00 & 0.00 & 2.34 & 9.35 & 21.03 & 27.27 & 28.82 & 30.38 & 31.94 & 32.72 & 32.72 & 73.36 & 26.64 & 1936.86 \\
\hline \multicolumn{17}{|c|}{ Estimated efficiency, the value of bound water $-42 \%$} \\
\hline 1. & Blank test & 0 & 0.00 & 0.00 & 0.00 & 0.00 & 0.00 & 0.80 & 0.80 & 0.80 & 1.20 & 1.60 & 2.40 & 5.71 & 94.29 & 5940.9 \\
\hline 2. & $\begin{array}{l}\text { obtained } \\
\text { demulsifier }\end{array}$ & 220 & 0.00 & 6.84 & 10.64 & 12.92 & 15.20 & 18.24 & 19.00 & 19.76 & 20.52 & 20.52 & 21.28 & 50.67 & 49.33 & 2014.67 \\
\hline 3. & $\begin{array}{l}\text { obtained } \\
\text { demulsifier }\end{array}$ & 260 & 0.00 & 6.23 & 9.35 & 13.24 & 15.58 & 17.92 & 18.70 & 20.25 & 20.25 & 21.03 & 21.03 & 50.08 & 49.92 & 2639.58 \\
\hline
\end{tabular}

Table 4. - The results of the study of the kinetics of the approximate and refined effective dosage of the demulsifier DE- 1 at a test temperature of $90^{\circ} \mathrm{C}$ for the North Pamuk oil

\begin{tabular}{|c|c|c|c|c|c|c|c|c|c|c|c|c|c|c|c|c|}
\hline \multirow[b]{3}{*}{ № } & \multirow[b]{3}{*}{ Product } & \multirow{3}{*}{ 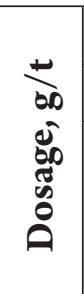 } & \multicolumn{11}{|c|}{ The amount of released water,\% } & \multirow{3}{*}{ 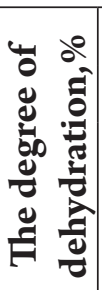 } & \multirow{3}{*}{ 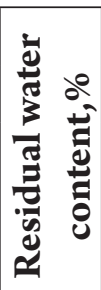 } & \multirow{3}{*}{ 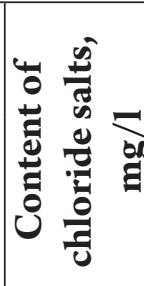 } \\
\hline & & & \multicolumn{11}{|c|}{ Time, $\min$} & & & \\
\hline & & & 5 & 10 & 15 & 20 & 30 & 40 & 50 & 60 & 75 & 90 & 120 & & & \\
\hline 1 & 2 & 3 & 4 & 5 & 6 & 7 & 8 & 9 & 10 & 11 & 12 & 13 & 14 & 15 & 16 & 17 \\
\hline \multicolumn{17}{|c|}{ Estimated efficiency, the value of bound water $-44 \%$} \\
\hline 1. & Blank test & 0 & 0.00 & 0.00 & 0.16 & 2.40 & 3.20 & 4.00 & 4.80 & 4.80 & 5.60 & 6.40 & 7.20 & 16.36 & 83.64 & 6749.2 \\
\hline 2. & $\begin{array}{l}\text { obtained } \\
\text { demulsifier }\end{array}$ & 150 & 0.08 & 4.50 & 8.26 & 11.26 & 14.26 & 20.26 & 21.76 & 24.02 & 24.77 & 24.77 & 24.77 & 56.29 & 43.71 & 2334.15 \\
\hline 3. & $\begin{array}{l}\text { obtained } \\
\text { demulsifier }\end{array}$ & 200 & 0.00 & 2.34 & 5.45 & 9.35 & 13.24 & 19.48 & 21.03 & 23.37 & 23.37 & 24.15 & 24.93 & 56.65 & 43.35 & 2248.65 \\
\hline 4. & $\begin{array}{l}\text { obtained } \\
\text { demulsifier }\end{array}$ & 240 & 0.15 & 3.80 & 6.84 & 9.88 & 14.44 & 17.48 & 20.52 & 22.80 & 23.56 & 24.32 & 25.08 & 57.00 & 43.00 & 1054.22 \\
\hline 5. & $\begin{array}{l}\text { obtained } \\
\text { demulsifier }\end{array}$ & 300 & 0.04 & 3.12 & 7.01 & 10.91 & 16.36 & 22.59 & 25.71 & 26.49 & 27.27 & 27.27 & 28.04 & 63.74 & 36.26 & 688.75 \\
\hline
\end{tabular}




\begin{tabular}{|l|c|c|c|c|c|c|c|c|c|c|c|c|c|c|c|c|}
\hline $\mathbf{1}$ & $\mathbf{2}$ & $\mathbf{3}$ & $\mathbf{4}$ & $\mathbf{5}$ & $\mathbf{6}$ & $\mathbf{7}$ & $\mathbf{8}$ & $\mathbf{9}$ & $\mathbf{1 0}$ & $\mathbf{1 1}$ & $\mathbf{1 2}$ & $\mathbf{1 3}$ & $\mathbf{1 4}$ & $\mathbf{1 5}$ & $\mathbf{1 6}$ & $\mathbf{1 7}$ \\
\hline \multicolumn{10}{|c|}{ Estimated efficiency, the value of bound water $-42 \%$} \\
\hline 1. & $\begin{array}{l}\text { obtained } \\
\text { demulsifier }\end{array}$ & 0 & 0.00 & 0.00 & 0.00 & 0.00 & 0.00 & 0.80 & 0.80 & 0.80 & 1.20 & 1.60 & 2.40 & 5.71 & 94.29 & 5940.9 \\
\hline 2. & $\begin{array}{l}\text { obtained } \\
\text { demulsifier }\end{array}$ & 220 & 0.00 & 6.84 & 12.92 & 15.96 & 19.76 & 21.28 & 22.04 & 22.80 & 22.80 & 22.80 & 22.80 & 54.29 & 45.71 & 1478.39 \\
\hline 3. & $\begin{array}{l}\text { obtained } \\
\text { demulsifier }\end{array}$ & 260 & 0.00 & 7.79 & 13.24 & 15.58 & 20.25 & 22.59 & 22.59 & 23.37 & 24.15 & 24.15 & 24.15 & 57.50 & 42.50 & 1038.73 \\
\hline
\end{tabular}

As a result, the efficiency evaluation from the obtained demulsifier line was continued to clarify the optimal effective dosage.

With the introduction of obtained demulsifier (tab. 3) at a dose of 240 and $300 \mathrm{~g} / \mathrm{t}$ to the oil emulsion, a decrease in the chloride salts content (from 7.12 to $1.94 \mathrm{~g} / \mathrm{t}$

1) more than three times is observed. The degree of dehydration reaches a maximum value at $300 \mathrm{~g} / \mathrm{t}$ and is $73.36 \%$, while the same effect is achieved when using $240 \mathrm{~g} / \mathrm{t}$ of base reagent. Commercial (separated) water does not grow cloudy, there is a clear phase boundary, there is no intermediate layer, no precipitate is formed and adhesion to the walls of the tube is not established.

The results of the obtained demulsifier, are presented in (table 4) show that with the introduction of it into the oil-water emulsion, a significant decrease in chloride salts to $0.69 \mathrm{~g} / 1$ is observed. With other things being equal, the obtained demulsifier com- pared to two other obtained demulsifiers from the same line) at a dosage of $300 \mathrm{~g} / \mathrm{t}$ is more effective, the degree of dehydration reaches a maximum value of $63.74 \%$. Compared to the base, the demulsifier does not provide sufficiently good dehydration at a specific consumption of $240 \mathrm{~g} / \mathrm{t}$.

With the introduction of the demulsifier into the water-oil emulsion, the released water does not become cloudy, there is a clear phase boundary, there is no intermediate layer, adhesion to the walls of the tube is not formed, but visually present in a small amount of sediment.

Thus, it was established that when preparing Western Toshli and Toshli oil, the consumption rate of the developed demulsifier is $2-1.5$ times less than for the known and amounts to 5 and $10 \mathrm{~g} / \mathrm{t}$ of oil, respectively. It is noted that the rate of separation of water-oil emulsion when using a new demulsifier is higher.

\section{References:}

1. Kasparyants K. S. Oil field preparation / K. S. Kasparyants.- M.: Nedra, 1973.- 376 p.

2. Levchenko D.N. Oil emulsions with water and methods for their destruction / D. N. Levchenko, N. V. Bergstein, A. D. Khudyakova, N. M. Nikolaev.-M.: Chemistry, 1967.- 200 p.

3. Pozdnyshev G. N. Stabilization and destruction of oil emulsions / G. N. Pozdnyshev.- M.: Nedra, 1982.$224 \mathrm{p}$.

4. Dehydration and desalting of oil: Chemical encyclopedia / F. M. Khutoryansky.-M.: Scientific. ed. Great Russian Encyclopedia.- V. 3. 1992.- P. 608-610.

5. Levchenko D. N. Oil desalting technology at oil refineries / D. N. Levchenko, N. V. Bergstein, N. M. Nikolaev.-M.: Chemistry, 1985.- 168 p.

6. Khutoryansky F. M. A comprehensive program for the preparation of oil and chemical-technological corrosion protection of condensation-refrigeration equipment of primary oil refining plants / F. M. Khutoryansky and others // World of petroleum products.- M. 2002.- No. 3.- P. 17-22. 